\title{
Masa Tenisi Antrenmanlarının Çocukların Öz-Yeterlik Algıları ve Problem Çözme Becerilerine Etkileri
}

\section{The Effects of Table Tennis Training on Children's Self-Efficacy and Problem Solving Skill Perceptions}

\author{
Nilgün Vurgun $^{1 *}$, Hikmet Vurgun ${ }^{1}$, Canan Aldırmaz ${ }^{2}$, Nevzat Mutlutürk ${ }^{1}$ \\ ${ }^{1}$ Manisa Celal Bayar Üniversitesi Spor Bilimleri Fakültesi, Manisa, Türkiye \\ ${ }^{2}$ Ege Üniversitesi Spor Bilimleri Fakültesi, İzmir, Türkiye
}

e-mail: nilvurgun@hotmail.com,hvurgun@yahoo.com, cananaldirmaz@gmail.com,nevzat.mutluturk@cbu.edu.tr ORCID: 0000-0001-7856-3303

ORCID: 0000-0001-6779-8000

ORCID: 0000-0001-8145-6066

ORCID: 0000-0001-8989-5916

*Sorumlu yazar/ Corresponding Author: Nilgün Vurgun

Gönderim Tarihi / Received: 20.02.2020

Kabul Tarihi / Accepted: 20.11.2020

DOI: $10.34087 /$ cbusbed.691922

\begin{abstract}
Öz
Giriş ve Amaç: Bu araştırmanın amacı 10-14 yaş grubu çocuklarda sekiz haftalık masa tenisi antrenmanlarının, çocukların öz-yeterlik ve problem çözme becerilerine yönelik algıları üzerindeki etkisini ortaya koymaktır.

Gereç ve Yöntemler: Araştırmaya, yaşları 10 ile 14 arasında değişen ( $\bar{x}=12,45, S=1,11) 20$ çalışma - 20 kontrol grubunda olmak üzere toplamda 40 öğrenci (16 kız, 24 oğlan) katılmıştır. Çalışma ve kontrol gruplarının ön-test ve son-test verileri Çocuk Öz-Yeterlik Ölçeği ve İlköğretim Düzeyindeki Çocuklar İçin Problem Çözme Envanteri kullanılarak elde edilmiştir. Çalışma grubu ön-test ölçümünü takip eden hafta itibariyle sekiz haftalık masa tenisi antrenmanlarına katılmıştır. Verilerin analizinde Wilcoxon İşaretli Sıralar Testi kullanılmıştır.

Bulgular: Grupların Çocuk Öz-Yeterlik Ölçeği öntest ve sontest verileri karşılaştırıldığında çalışma grubunda ölçeğe ait altboyutlarda anlamlı bir farklılık bulunmazken, kontrol grubunun Sosyal Özyeterlik altboyutunda anlamlı farklılık ortaya konmuştur $(\mathrm{p}<.05)$. Grupların İlköğretim Düzeyindeki Çocuklar İçin Problem Çözme Envanterine ait verilerin öntest-sontest karşılaştırmasında her iki grupta da istatistiksel olarak anlamlı bir değişiklik saptanmamıştır.

Sonuç: Sekiz haftalık masa tenisi antrenmanları ile çocukların öz-yeterlik ve problem çözme becerisi algıları artsa da anlamlı olarak bir değişiklik yaratmadığı görülmüştür. Buna ek olarak, çalışmaya dahil edilmeyen okul çağı çocuklarının Sosyal Öz-yeterlik algılarının olumsuz olarak etkilendiği sonucuna ulaşılmıştır.
\end{abstract}

Anahtar kelimeler: Masa tenisi, Öz-yeterlik, Problem çözme.

\footnotetext{
Abstract

Objective: The aim of this study is to reveal the effect of eight-week table tennis training on children's perceptions of self-efficacy and problem solving skills in 10-14 age group children.

Materials and Methods: A total of 40 students (16 girls, 24 boys), 20 study group - 20 in the control group, aged between 10 and 14 years $(\bar{x}=12,45, S=1,11)$ participated in the study. The pre-test and post-test data of the study and control groups were obtained by using the The Self-Efficacy Scale for Children and the Problem Solving Inventory for Children at the Level of Primary Education. The study group participated in eight-week table tennis training as of the week following the pre-test measurement. Wilcoxon test was used to analyze the data.

Results: Comparision of the pre-test and post-test data of The Self-Efficacy Scale for Children of the groups, in the study group there was no significant difference in the sub-dimensions of the scale, but in the control group a significant difference was found in the Social Self-Efficacy sub-dimension $(p<.05)$. There was no statistically significant change
} 
was found in both groups in the pre-test-post-test comparison of the data of the Problem Solving Inventory for Children at the Level of Primary Education.

Conclusion: Although the perceptions of self-efficacy and problem solving skills of children increased with eightweek table tennis training, it was observed there was no significant change in those variables. In addition, it was concluded that the social self-efficacy perceptions of school-age children who were not included in the study were negatively affected.

Keywords: Problem solving, Table tennis, Self-efficacy.

\begin{abstract}
1. Giriş
Sporun her yaş grubu için yararları biliniyor olsa da özellikle gelişim çağındaki çocukların hem fiziksel hem psikolojik iyi oluşlarına katkısı bir hayli fazladır. Büyükşehirlerde yaşayan çocukların çevre koşullarına bağlı olarak daha fazla sportif aktiviteye katılma firsatları vardır. Fakat kırsal ve küçük yerleşim yerlerinde yaşayan çocuklar bu firsatlardan yoksundur. Bu çocukların sportif aktiviteleri yapabilecekleri en uygun alanların okullar olduğu düşünülebilir. Masa tenisi, oyun alanı ve gereçleri kolaylıkla karşılanabilen sporlardan biridir. Masa tenisi antrenmanlarının çocuklar üzerindeki faydalarının ortaya konması ile okullarda bu sporun yaygınlaşması adına bir veri elde edilmesi beklenmektedir.

İnsanların başarılı olma ihtiyacı, psikososyal gelişim içinde kişinin kendine güvenini kazanması ve yetenek algısını arttırması ya da tazelemesi açısından önemlidir. Bunun en kolay yollarından biri de spordur [1] Spor, bireylere yetkin oldukları bir alanda başarı sağlama firsatı vermektedir [2].
\end{abstract}

Ergenlik dönemi bireyin fiziksel özelliklerini başkalarıyla kıyasladığı ve zaman zaman memnuniyetsizlikler yaşadığı bir dönemdir. Spor sayesinde ergenler fiziksel güçlerini arttırır, daha sağlıklı ve fit bir görünüm kazanırlar. Fiziksel öz yeterlik algıları artar [3]. Spor esnasinda salgilanan endorfin hormonu sayesinde vücut rahatlar ve stres atılır. Aynı zamanda spor sırasında kişi gün içinde yaşadığı stres yaratan unsurlardan uzaklaşır. Spor yaparak yaşadığı stres düzeyini azaltan birey daha verimli çalışmaya başlar ve bu verim diğer pek çok alanda da daha başarılı performans sergilemesini sağlar. Problem çözme becerisine olan güven olumlu yönde etkilenir [2]. Bu bilgiler dikkate alındığında, ergenlik döneminde öz yeterlik algısının ve problem çözme becerisinin önemi anlaşılmaktadır.

Öz yeterlik, bireyin, belirli bir takım performans kriterlerini yerine getirebilmek için ortaya koyması gereken çabayı düzenleme ve gerçekleştirme becerisine yönelik algısıdır [4]. Öz yeterlik inancının yaşamın tüm dönemlerinde düzenleyici fonksiyonu olmakla beraber, özellikle ergenlik döneminde bir hayli önemli hale gelmektedir. Ergenlik dönemine yetersizlik duygusu ile giren birey, çevresel isteklere yeterli tepki vermeyecek ve karşılaştığı sorunlar tarafından daha kolay yıpratılacaktır [5]. Bu nedenle bireylerin genç yaştan itibaren özyeterlik algılarına katkı sağlanmalıdır. Yapılan araştırma sonuçları ergen bireylerin spora katılma durumlarının öz yeterlik algılarını desteklediğini göstermektedir [6]. Okul bağlamında incelendiğinde de benzer olumlu sonuçlarla karşılaşılmaktadır. Okul dışı spor katılımının genç bireylerin gelişimi üzerindeki etkilerinin incelendiği araştırmada öz yeterliğin olumlu yönde etkilendiği sonucu ortaya konmuştur [7].

Birey için önemli olan bir diğer psikolojik değişken de problem çözme becerisidir. Dinçer (1995) problemi, "bireyin bir hedefe ulaşmada engellenme ile karşılaştığ bir çatışma durumu" olarak tanımlamıştır [8]. Bu problem ve engeller bireyin hedeflerine ulaşmasını zorlaştırabilir. Engellemelerin üstesinden gelmek için en etkili yolu bulmak, problem çözme anlamına gelmektedir [9]. Lawson (1984)'a göre beden eğitimi ve spor problem çözmede en etkili olan alanlardan biridir çünkü bireyin sosyal yaşam içerisinde kişisel, kültürel, sosyal ve ekonomik olarak karşılaşabileceği çok boyutlu sorunların çözüm sürecinde rol oynamaktadır [10]. Mirzeoğlu, Özcan ve ark. (2010) bu görüșü şu ifadelerle desteklemektedir: "Kendi yetenek alanlarında lisans belgeleri çıkartılarak okul içinde ve dışındaki sportif karşılaşmalara çıkan öğrenciler, yaptıkları spor branşını öğrenme, yeteneklerini en üst seviyeye çıkarma, sağlıklı beslenme, aldığı diğer derslerde başarılı olma, kendisini ve oyuncusu olduğu grubu temsil etme, kişiliği ve ahlakıyla da yaptığı sporda kalıcılığını garantileme gibi özellikler kazanırken, aynı zamanda spor ortamlarında karşılaştıkları sorunları aşmaya çalışarak problem çözme becerisi de kazanmış olurlar" [11]. Vatansever ve Özen (2017) tarafindan yapılan çalışma sonuçları da bu varsayımı destekler niteliktedir [12]. $\mathrm{Bu}$ çalışma sonuçlarına göre, 12 hafta boyunca tenis antrenmanı yapan öğrencilerin problem çözme becerilerinin olumlu yönde arttığı ortaya konmuştur. Bir başka çalışmada, spor alanında eğitim alan bireylerin almayanlara kıyasla problem çözme becerilerinin yüksek olduğu bulunmuştur [13].Canan ve Ataoğlu (2010) tarafindan gerçekleştirilen araştırma bulguları da benzer sonuçlar ortaya koymuştur. Takım sporlarıyla uğraşan bireylerin algılanan problem çözme becerilerinin bireysel sporculara ve sedanter bireylere kıyasla daha yüksek olduğu bulunmuştur [14]. Yapılan literatür taraması sonucunda problem çözme becerisi ve masa tenisi ile ilgili bir araştırmaya rastlanmamıştır. Bu bağlamda, yapılan bu araştırmanın alan yazına, masa tenisi ile uğraşan bireylere ve beden eğitimi öğretmenlerine katkı sağlayacağı düşünülmektedir.

Spor ve fiziksel aktivitenin öz yeterlik ve problem çözme becerileri üzerindeki olumlu etkileri dikkate alındığında, her yaştan insanın kolayca ulaşabildiği ve özellikle küçük yaş guruplarında uygulama kolaylığına sahip olan masa tenisi antrenmanlarının bu psikolojik özellikler ürerindeki etkisinin araştırılması planlanmaktadır.

\section{Materyal ve Metot \\ 2.1. Katılımcilar}


Bu çalışma, MEB Simav Güney Ortaokulunda öğrenim gören, yaşları 10 ile 14 arasında değişen $(\bar{x}=12,45$, $\mathrm{Ss}=1,11)$ toplamda 40 öğrenciden (16 k1z, 24 oğlan) oluşmuştur. Öğrenciler çalışma ve kontrol grubu olmak üzere iki eşit gruba ayrılmıştır. Bu çalışmadaki tüm veriler Helsinki Bildirgesi'nin etik standartlarına uygun olarak toplanmıştır. Yerel etik komite çalışma protokolünü onaylamış ve gönüllülerden bilgilendirilmiş onam alınmıştır.

\subsection{Veri Toplama Araçlart}

\subsection{1. Çocuklar $\dot{I}$ çin Öz Yeterlik Ölçeği (ÇÖYÖ):}

Muris (2007) tarafindan ergenler için geliştirilen ölçek [15], Telef (2011) tarafindan hem hem ilköğretim hem de ortaöğretim öğrencilerini kapsayacak şekilde Türkçe'ye uyarlanmıştır [5]. Ölçek, üç alt boyuttan oluşmaktadır: (a) Sosyal Öz-yeterlik (SÖY), ergenlerin akran ilişkilerini ve girişkenlik yeteneğini fark etme düzeylerine yönelik ifadderi içerirken; (b) Akademik Özyeterlik (AÖY), ergenlerin akademik beklentilerini gerçekleştirme, akademik konuları başarma ve kişinin kendi öğrenme davranışını yönetme yeteneğini algılaması ile ilgili ölçümleri kapsamaktadır ve son olarak (c) Duygusal Öz-yeterlik (DÖY) ise ergenlerin olumsuz duygularıyla baş etme yeteneğini algılamayı ölçmektedir [5]. Beşli likert ( $1=$ hiç ve $5=$ çok iyi) olan ve toplamda 21 madde bulunan ölçeğin her alt boyutu için yedi madde yer almaktadır.

\subsubsection{Illköğretim Düzeyindeki Çocuklar Iç̧in Problem Çözme Envanteri}

Serin, Serin ve ark. (2010) tarafindan ilköğretim öğrencilerinin problem çözme becerisi ile ilgili kendilerini algılama düzeylerini ölçmek amacıyla geliştirlen ölçek "Problem Çözme Becerisine Güven” (12 madde), "Öz Denetim" (7 madde) ve "Kaçınma" (5 madde) olmak üzere üç faktör ve toplamda 24 maddeden oluşmaktadır [16]. Problem Çözme Becerisine Güven faktörüne ait maddeler problemler karşısında kendine güveni, vazgeçmemeyi, kararlılığı ifade etmektedir. Öz Denetim faktöründe yer alan maddeler problem karşısında kendini yönetebilme, daha özerk davranışlar, düşünceler geliştirebilme, iç denetimli özelliklerinin baskınlığı ile ilgili ifadeler yer almaktadır. Son olarak Kaçınma faktörü ise, bir problemle karşılaştığında sorununu çözmek yerine erteleme, yoksayma, yüzleşememe, gerçek sorundan uzaklaşma eğiliminin ağır basması ile ilgili maddeler içermektedir [16]. Öz Denetim ve Kaçınma altboyutuna ait tüm maddeler ters çevirelerek hesaplanmaktadır. Ölçek beşli likert tipi olup, 1- "Hiçbir zaman böyle davranmam"1 ifade ederken, 5"Her zaman bölye davranırım"1 ifade etmektedir. Ölçekten alınan toplam puanların yüksekliği, bireylerin problem çözme konusunda kendini yeterli algıladığını göstermektedir.

\subsection{Prosedür}

Çalışma grubu, okul sporlarında yıldızlar ve küçükler kategorisinde yarışmak için beden eğitimi öğretmeni tarafından belirlenmiş olan 20 kişiden oluşmaktadır. Kontrol grubu öğrencileri çalışma grubunda yer alan öğrencilerle aynı seviyede eğitim gören bireylerden oluşmaktadır. $\mathrm{Bu}$ nedenle, grupların oluşturulması sırasında ölçeklerden elde edilen öntest puanlarına göre eşit bir dağılım yapılamamıştır. Çalışma ve kontrol grubunda yer alan 40 öğrenciden Tüm katılımcılar 1 . haftada öncelikle Çocuklar İçin Özyeterlik Ölçeğini ve İlköğretim Düzeyindeki Çocuklar İçin Problem Çözme Envanterini doldurmaları istenerek ön-test verileri toplanmıştır. Ön-test verileri elde edildikten sonra çalışma grubuna 2. haftadan itibaren 8 hafta süreyle devam eden, haftada 3 gün 90'ar dakikalık masa tenisi antrenmanları uygulanmıştır. Kontrol grubu ise bu antrenmanlara dahil olmamış, yalnızca günlük aktivitelerine devam etmiştir. 8 haftalık sürenin ardından 10. haftada katılımcıların tamamına 1 . hafta uygulamış oldukları ölçüm araçları tekrar uygulanarak son-test verilerileri toplanmıştır.

\subsection{Istatistiksel Veri Analizi}

Katılımcılardan Simav Güney Ortaokulunda envanterler aracılığı ile elde edilen veriler SPSS paket program 125.0 sürümü ile analiz edilmiştir. Öncelikle analizi yapılan verilerin ortalama ve standart sapma değerleri hesaplanmıştır. Ardından, verilerin normal dağılıma uygunluk göstermemesi nedeniyle parametrik olmayan testlere başvurulmuştur. Verilerin analizinde tanımlayıcı istatistiklere ek olarak, grupların ön-test ve son-test verilerini karşılaştırmak için Wilcoxon İşaretli Sıralar Testi kullanılmıştır. Bütün testlerde anlamlılık düzeyi $\mathrm{p}<$ 0.05, güvenirlik aralığ1 \%95 olarak kabul edilmiştir.

\section{Bulgular}

Çalışma grubunun ÇÖYÖ'ne ait verilerine uygulanan Wilcoxon işaretli sıralar testine göre, katılımcıların öntest puanları ile sekiz haftalık masa tenisi egzersiz uygulaması ardından elde edilen sontest puanları arasında ölçeğin AÖY $(Z=.53, p=.60)$, SÖY $(Z=.48$, $\mathrm{p}=.63)$ ve DÖY $(\mathrm{Z}=1.72, \mathrm{p}=.086)$ altboyutlarında istatistiksel olarak anlamlı bir farklılık olmadığını ortaya koymuştur.

Kontrol grubunun ÇÖYÖ'ne ait verileri Wilcoxon işaretli sıralar testi ile analiz edildiğinde, AÖY $(Z=1.11$, $\mathrm{p}=.27)$ ve DÖY $(\mathrm{Z}=.36, \mathrm{p}=.72)$ altboyutlarında öntest ve sontest puanlarının anlamlı olarak farklılaşmadığ görülürken, SÖY altboyutunda sontest puanlarının öntest puanlarına göre istatistiksel olarak daha düşük olduğu sonucuna ulaşılmıştır $(Z=2.36, \mathrm{p}=.018)$.

Çalışma grubunun sekiz haftalık masa tenisi egzersiz programının ardından ÇPÇE'ne ait öntest ve sontest puanları arasında bir fark olup olmadığını test etmek amacıyla gerçekleştirilen Wilcoxon işaretli sıralar testine göre, ölçeğin PÇG $(Z=.81, p=.42)$, PÇÖ $(Z=.79, p=$ $.43)$ ve $\mathrm{PÇK}(\mathrm{Z}=.15, \mathrm{p}=.88)$ istatistiksel olarak bir farklılık saptanmamıştır. 
Tablo 1. Çalışma grubunun Çocuk Öz-Yeterlik Ölçeğine ait öntest-sontest verilerinin karşılaştırılması

\begin{tabular}{|c|c|c|c|c|c|c|c|c|c|}
\hline & \multicolumn{3}{|c|}{ Negatif Sıralar } & \multicolumn{3}{|c|}{ Pozitif Sıralar } & \multicolumn{3}{|c|}{ Test İstatistikleri } \\
\hline & $n$ & S.O & S.T & $n$ & S.O & S.T & Eşit & $Z$ & $p$ \\
\hline $\begin{array}{l}\text { (AÖY sontest)- } \\
\text { (AÖY öntest) }\end{array}$ & 8 & 9,19 & 73,50 & 10 & 9,75 & 97,50 & 2 &,$- 525^{\mathrm{a}}$ & ,600 \\
\hline $\begin{array}{l}\text { (SÖY sontest)- } \\
\text { (SÖY öntest) }\end{array}$ & 8 & 8,31 & 66,50 & 9 & 9,61 & 86,50 & 3 &,$- 478^{a}$ & ,630 \\
\hline $\begin{array}{l}\text { (DÖY sontest)- } \\
\text { (DÖY öntest) }\end{array}$ & 5 & 10,50 & 52,50 & 14 & 9,82 & 197,50 & 1 & $-1,715^{\mathrm{a}}$ &, 086 \\
\hline
\end{tabular}

Tablo 2. Kontrol grubunun Çocuk Öz-Yeterlik Ölçeğine ait öntest-sontest verilerinin karşılaştırılması

\begin{tabular}{|c|c|c|c|c|c|c|c|c|c|}
\hline \multirow{2}{*}{ ÇÖYÖ } & \multicolumn{3}{|c|}{ Negatif Siralar } & \multicolumn{3}{|c|}{ Pozitif Sıralar } & \multicolumn{3}{|c|}{ Test İstatistikleri } \\
\hline & $n$ & S.O & S.T & $n$ & S.O & S.T & Eşit & $Z$ & $p$ \\
\hline $\begin{array}{l}\text { (AÖY sontest)- } \\
\text { (AÖY öntest) }\end{array}$ & 11 & 10,09 & 111 & 7 & 8,57 & 60 & 2 & $-1,114^{a}$ & ,265 \\
\hline $\begin{array}{l}\text { (SÖY sontest)- } \\
\text { (SÖY öntest) }\end{array}$ & 13 & 12,92 & 168 & 7 & 6 & 42 & 0 & $-2,362^{\mathrm{a}}$ &,$- 018^{*}$ \\
\hline $\begin{array}{l}\text { (DÖY sontest)- } \\
\text { (DÖY öntest) }\end{array}$ & 9 & 8,33 & 75 & 7 & 8,71 & 61 & 4 &,$- 363^{\mathrm{a}}$ & ,716 \\
\hline
\end{tabular}

*p<0,05; a Pozitif sıralar temel alınarak. ÇÖYÖ=Çocuk Öz-Yeterlik Ölçeği; AÖY=Akademik öz-yeterlik, SÖY=Sosyal öz-yeterlik; DÖY=Duygusal öz-yeterlik

Tablo 3 Çalışma grubunun İlköğretim Düzeyindeki Öğrenciler İçin Problem Çözme Envanterine ait öntest-sontest verilerinin karşılaştırılması

\begin{tabular}{|c|c|c|c|c|c|c|c|c|c|}
\hline & \multicolumn{3}{|c|}{ Negatif Suralar } & \multicolumn{3}{|c|}{ Pozitif Siralar } & \multicolumn{3}{|c|}{ Test İstatistikleri } \\
\hline & $n$ & S.O & S.T & $n$ & S.O & S.T & Eşit & $Z$ & $p$ \\
\hline $\begin{array}{l}\text { (PÇG sontest)- } \\
\text { (PÇG öntest) }\end{array}$ & 9 & 9,28 & 83,50 & 11 & 11,50 & 126,50 & 0 &,$- 805^{\mathrm{a}}$ & ,421 \\
\hline $\begin{array}{l}\text { (PÇÖ sontest)- } \\
\text { (PÇÖ öntest) }\end{array}$ & 8 & 8,44 & 67,50 & 10 & 10,35 & 103,50 & 2 & $-.786^{\mathrm{a}}$ & ,432 \\
\hline $\begin{array}{l}\text { (PÇK sontest)- } \\
\text { (PÇK öntest) }\end{array}$ & 8 & 10,25 & 82 & 10 & 8,90 & 89 & 2 & $-.153-^{\mathrm{a}}$ & ,878 \\
\hline
\end{tabular}

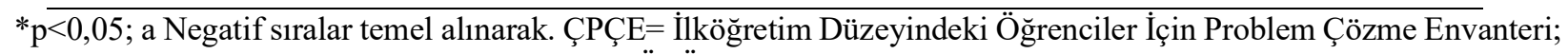
$\mathrm{PÇG=Problem} \mathrm{Çözme} \mathrm{Becerilerine} \mathrm{Güven;} \mathrm{PÇO}=\mathrm{Özdenetim;} \mathrm{PÇK=Kaçınma}$ 
Tablo 4 Kontrol grubunun İlköğretim Düzeyindeki Öğrenciler İçin Problem Çözme Envanteri’ne ait öntest-sontest verilerinin karşılaştırılması

\begin{tabular}{|c|c|c|c|c|c|c|c|c|c|}
\hline & \multicolumn{3}{|c|}{ Negatif Sıralar } & \multicolumn{3}{|c|}{ Pozitif Siralar } & \multicolumn{3}{|c|}{ Test İstatistikleri } \\
\hline & $n$ & S.O & S.T & $n$ & S.O & S.T & Eşit & $Z$ & $p$ \\
\hline $\begin{array}{l}\text { (PÇG sontest)- } \\
\text { (PÇG öntest) }\end{array}$ & 9 & 10,89 & 98 & 9 & 8,11 & 73 & 2 &,$- 545^{a}$ &, 59 \\
\hline $\begin{array}{l}\text { (PÇÖ sontest)- } \\
\text { (PÇÖ öntest) }\end{array}$ & 12 & 10,46 & 125,50 & 6 & 7,58 & 45,50 & 2 & $-1,748^{a}$ & ,08 \\
\hline $\begin{array}{l}\text { (PÇK sontest)- } \\
\text { (PÇK öntest) }\end{array}$ & 9 & 7,33 & 66 & 7 & 10 & 70 & 4 &,$- 104^{\mathrm{b}}$ & ,92 \\
\hline
\end{tabular}

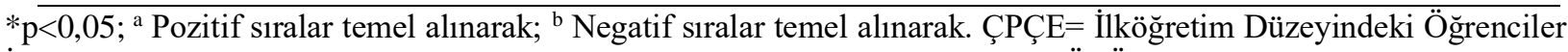
İçin Problem Çözme Envanteri; PÇG=Problem Çözme Becerilerine Güven; PÇÖ=Özdenetim; PÇK=Kaçınma

Kontrol grubunun ÇPÇE'ne ait Wilcoxon işaretli sıralar analiz sonuçlarına göre, ölçeğin altboyutları olan $\mathrm{PÇG}(\mathrm{Z}$ $=.55, \mathrm{p}=.59)$, PÇÖ $(\mathrm{Z}=1.75, \mathrm{p}=.08)$ ve PÇK $(\mathrm{Z}=.10$, $\mathrm{p}=.92)$ altboyutlarının tamaminda, öntest ve sontest verileri arasında istatistiksel olarak anlamlı bir farklılı̆̆ın olmadığı ortaya konmuştur.

\section{Tartışma}

Çalışma grubuna ait öntest ve sontest puanlarının karşılaştırılmasına yönelik yapılan Wilcoxon İşaretli Sıralar Test sonuçlarına göre (Tablo 1) ÇÖYÖ'ne ait altboyutlarda sontest sonuçları öntest puan ortalamalarından yüksek olsa da istatistiksel olarak anlamlı bir sonuç bulunamamıştır. Öz-yeterlik algısının 8 haftalık masa tenisi antrenmanı sonucunda artmış olmasın rağmen anlamlı düzeyde bir farklılık ortaya konmaması, uygulama süresinden kaynaklanmış olabilir. Benzer şekilde kontrol grubunun öntest ve sontest puan ortalamalarının karşılaştırılmasında (Tablo 2) AÖY ve DÖY altboyutlarında anlamlı farklılık bulunmazken, SÖY altboyutunda sontest puanlarının öntest puanlarına göre istatistiksel olarak düşük olduğu tespit edilmiştir. $\mathrm{Bu}$ durumun, küçük bir popülasyona sahip olan bir okulda eğitim gören öğrencilerin, çalışma grubunda yer alan arkadaşlarının olması nedeniyle kendilerinin antrenman programına dâhil edilmeyerek sosyal olarak dişarıda bırakılmış hissetmelerinden kaynaklanmış olabileceği düşünülmektedir.

Fiziksel aktivite ve egzersizlerin öz-yeterlik üzerindeki olumlu etkileri bilinmektedir. Pant (2016), masa tenisi sporcularının öz-yeterlik düzeylerinin büyük oranda yüksek olduğunu ortaya koymuştur [17]. Masa tenisi antrenmanlarının öz-yeterlik üzerindeki etkilerini araştıran çalışmaya rastlanmamış olsa da farklı sportif ve fiziksel aktivitelerin etkisini araştıran çalışmalar vardır. Eyüboğlu (2012) tarafindan 12-14 yaş çocukları üzerinde gerçekleştirilen araştırma sonucuna göre, spor yapan çocukların öz-yeterlik düzeylerinin spor yapmayanlara kıyasla anlamlı olarak daha yüksek olduğu bulunmuştur [18]. Moritz, Feltz ve ark. (2000)'nın yapmış olduğu geniş kapsamlı meta-analitik çalışmada, öz-yeterlik ve performans arasında istatistiksel olarak yüksek pozitif korelasyon olduğu ortaya konmuştur [19]. Egzersiz deneyimleri, bireylerin kendilerine yönelik algıları için bir yeterlik bilgi kaynağı olarak işlev görmektedir. Düzenli olarak egzersiz yapan bireyin beceri düzeyinin artması beklendik bir durumdur. Buna bağlı olarak da bireyin öz-yeterlik düzeyine ilişkin algısının artması da mümkün olabilir. Düzenli sportif aktiviteye dâhil olan bireylerin, sportif becerilerine ek olarak duygularını kontrol etme ve yönlendirme gibi becerileri de beraberinde geliştirdikleri öne sürülebilir. Ayrıca, bir konuda yetkinlik algısı artan bireyin, geliştirmiş olduğu bu özelliği diğer alanlara da pozitif transfer yoluyla aktarması beklenebilir. Düzenli antrenman ve egzersiz sayesinde sportif beceri düzeyi artan bireyin, çalışma yoluyla akademik başarısını geliştirebileceğine olan inancının da artması da mümkün olabilir. Araştırmamızda, antrenman yapan bireylerin öz-yeterlik seviyesindeki istatistiksel olarak anlamlı olmayan artışın bunlara bağlı olarak gerçekleşmiş olabileceği düşünülmektedir. Efe, Öztürk ve ark. (2008), 14-16 yaş grubu erkeklerde 36 haftalık voleybol antrenmanlarının sosyal yetkinlik düzeylerinin anlamlı derecede artırdığını ortaya koymuştur [20]. $\mathrm{Bu}$ sonucun aksine, araştırmamızda 8 haftalık masa tenisi antrenmanlarının sosyal öz-yeterlik düzeyinde anlamlı bir artışa neden olmadığı ortaya konmuştur. Bu durum, sekiz haftalık antrenman süresinin sosyal öz-yeterlik anlamında bir değişiklik meydana gelmesi için kısa bir süre olmasından kaynaklanıyor olabilir. Bununla beraber, araştırmada yer alan katılımcılar küçük yerleşim yerlerinden olan bir beldede yaşadıklarından, hali hazırda var olan etkileşim gruplarına ek olarak sosyal etkileşim kurabilecekleri çevrenin kısıtlı olmasından dolayı, bu öz-yeterlik düzeyinde beklenen artışın gerçekleşememiş olması düşünülebilir.

Sekiz haftalık masa tenisi antrenmanlarının çalışma grubu üzerindeki etkisini incelemek için Wilcoxon İşaretli Sıralar Testi uygulanmıştır (Tablo 3). Çalışma grubunun ÇPÇE'ne ait sontest puanlarının beklendiği üzere öntest puanlarından yüksek olsa da istatistiksel 
olarak anlamlı derecede bir farklılık oluşmamıştır. Kontrol grubu incelendiğinde ise aynı şekilde ölçeğe ait altboyutlarda sontest ve öntest puanları arasında anlamlı farklılık saptanmamıştır (Tablo 4). Egzersizlerin problem çözme becerisi üzerinde bir artışa neden olsa da, anlamlı derecede bir artış olmayışı, problem çözme için gerekli olan bilişsel gelișim açısından sekiz haftalık sürenin yetersiz gelmiş olabileceği düşünülmektedir.

Alan yazın incelendiğinde masa tenisi ile problem çözme becerisi arasındaki ilişkiyi ortaya koyan, masa tenisi antrenmanlarının problem çözme üzerindeki etkisini araştıran çalışmaya rastlanmamıştır. Bununla beraber, düzenli egzersizlerin problem çözme becerisine etkisinin araştırıldığı, spor yapan bireylerin spor yapmayanlarla kıyaslandığı araştırmalar bulunmaktadır. Spor yapan bireylerin yapmayanlara kıyasla daha yüksek problem çözme becerisine sahip oldukları Mirzeoğlu, Özcan ve ark. (2010) tarafindan lise öğrencileri arasında gerçekleştirilen çalışmada ortaya konmuştur [11]. Egzersiz etkilerinin problem çözme becerisi üzerindeki etkisinin araştırılmak istendiği çalışmada Vatansever ve Özen (2017), 12 hafta boyunca düzenli olarak tenis eğitimine katılan bireylerle katılmayan bireyleri karşılaştırmışlardır [12]. Çalışma sonucunda, problem çözme ölçeğine ait öntest puanlarında gruplar arasında anlamlı farklılık bulunmazken, 12 haftanın sonunda tenis egzersizi yapan grubun sontest puanlarının artmış olduğu görülmüştür. Kontrol grubunun öntest ve sontest puanları arasında bir farklılık görülmezken, egzersiz yapan grubun öntest ve sontest puanlarının karşılaştırılmasında, problem çözme becerisine ait altboyutlarda anlamlı farklılıklar olduğu ortaya konmuştur. Bir başka çalışmada, 11-14 yaş grubu çocuklara 10 hafta süreyle düzenli olarak futbol antrenmanı yaptırılmıștır [21]. Çalışma sonuçları bizim bulgularımızdan farklılık göstermektedir. Bulgulara göre, egzersiz yapan grup ile kontrol grubunun puan ortalamalarının karşılaştırılmasında, öntest sonuçlarında ve sontest sonuçlarında anlamlı farklılık bulunmazken, deney grubunun sontest puanlarının öntest puanlarından istatistiksel olarak yüksek olduğunu ortaya koymuşlardır. Canan ve Ataoğlu (2010) yapmış oldukları araştırmada bireysel sporların problem çözme becerisi algısı üzerinde etkisi olmamasına karşın, takım sporlarının problem çözme becerisi algısını artırdığı ortaya konmuşlardır [14]. Araştırmamızda problem çözme becerisi algısında pozitif yönlü anlamlı bir artış sağlanmamasının masa tenisinin bireysel bir spor olmasından kaynaklanmış olabileceği düşünülmektedir.

\section{Sonuc}

Sonuç olarak, düzenli olarak gerçekleştirilen sekiz haftalık masa tenisi antrenmanlarının okul çağında bulunan çocukların öz-yeterlik ve problem çözme becerisi algısı gibi iki önemli psikolojik özelliği geliştirdiği ancak anlamlı olarak bir farklılık yaratmadığ ortaya konmuştur. Uygulama süresinin uzatılarak tekrar gerçekleştirilecek olan çalışmalar konuya bir 1 şık tutabilir. Bunun yanı sıra, özellikle az mevcutlu okullarda bir grup fiziksel aktivite firsatlarından yararlanırken diğer grubun bu yoksun bırakılmasının okul çağı çocuklarının sosyal öz-yeterlik algılarını olumsuz etkilemiş olabileceği sonucuna ulaşılmıştır. $\mathrm{Bu}$ yaş gurubu örneklemlere farklı spor dalları ve daha uzun süreli olarak gerçekleştirilecek olan gelecek çalışmaların konuya daha fazla açıklı getirebileceği öngörülmektedir.

\section{Teşekkür ve Bilgilendirme}

Manisa Celal Bayar Üniversitesi Bilimsel Araştırma Projeleri Koordinasyon Birimine, araştırmaya sağlamış oldukları maddi destekten dolayı teşekkür ederiz.

Araştırmanın uygulama yeri için gerekli izinleri vermiş olan Kütahya Simav İlçe Milli Eğitim Müdürlüğüne, Simav Güney Ortaokuluna teşekkür ederiz.

$\mathrm{Bu}$ çalışma 17. Uluslararası Spor Bilimleri Kongresinde özet bildiri olarak sunulmuştur.

\section{Referanslar}

1. Küçük, V, Koç, Harun, Psiko-Sosyal Gelişim Süreci İçerisinde İnsan Ve Spor İlişkisi, Dumlupınar Üniversitesi Sosyal Bilimler Dergisi, 2004, 9.

2. Çakıc1, D, Spor lisesi ve genel lise 9. ve 10. sınıf öğrencilerinin sosyal yetkinlik beklentisi ve özsayg1 düzeylerinin incelenmesi, Yüksek lisans tezi, Mersin Üniversitesi, Mersin, 2010.

3. Gün, E, Spor yapanlarda ve spor yapmayan ergenlerde benlik saygisı. Yüksek lisans tezi, Cukurova Üniversitesi Sağllk Bilimler Enstitüsü, Adana, 2006.

4. Bandura, A, Self-efficacy: toward a unifying theory of behavioral change, Psychological review, 1977, 84, 191-215.

5. Telef, B, Öz-yeterlikleri farklı ergenlerin psikolojik semptomlarının incelenmesi. Doktora Tezi, DË̈ Eğitim Bilimleri Enstitüsü, İzmir, 2011

6. Reverdito, R.S, Carvalho, H.M, Galatti, L.R, Scaglia, A.J, Gonçalves, C.E, Paes, R.R, Effects of youth participation in extracurricular sport programs on perceived self-efficacy: A multilevel analysis, Perceptual and motor skills, 2017, 124(3), 569-583.

7. Carreres-Ponsoda, F, Escartı, A, Cortell-Tormo, JM, Fuster-Lioret, $\mathrm{V}$, Andreu-Cabrera, E, The relationship between out-of-school sport participation and positive youth development, Journal of Human Sport and Exercise, 2012, 7(3), 671-683.

8. Dinçer, A, Anaokuluna Devam Eden 5 Yas Grubu Cocuklarına Kişiler Arası Problem Çözme Becerilerinin Kazandırılmasında Eğitimin Etkisinin İncelenmesi. Doktora Tezi, Hacettepe Üniversitesi Sosyal Bilimler Enstitüsü, Ankara, 1995.

9. Morgan, T.C, Psikolojiye Giriş (Çev: Rikzan Eski, Sibel Karakaş); Eğitim Kitabevi Yayınları: Ankara: Türkiye, 2009.

10. Lawson, H.A, Problem-setting for physical education and sport, Quest, 1984, 36(1): 48-60.

11. Mirzeoğlu, D, Özcan, G, Kıyak, Ö, Aydemir, F, Ortaöğretimde lisanslı olarak spor yapan ve spor yapmayan ögrencilerin problem çözme becerilerinin çeşitli değişkenlere göre incelenmesi, Gazi Beden Eğitimi ve Spor Bilimleri Dergisi, 2010, 15(2), 3-19.

12. Vatansever, S, Özen, G, Effect of tennis education on problem solving skills in university students Tenis eğitiminin üniversite öğrencilerinin problem çözme becerisi üzerine etkisi. Journal of Human Sciences, 2017, 14(1), 1-9.

13. Sozen, $H$, The effect of physical education and sports school training on problem solving skills of the athletes, Procedia-Social and Behavioral Sciences, 2012, 46, 4186-4190.

14. Canan, F, Ataoğlu, A, The influence of sports on anxiety, depression, and perceived problem solving ability, Anatolian Journal of Psychiatry, 2010, 11(38), 38-48.

15. Muris, $\mathrm{P}, \mathrm{A}$ brief questionnaire for measuring self-efficacy in youths Journal of Psychopathology and behavioral Assessment, 2001, 23(3), 145-149. 
16. Serin, O, Serin, N.B, Saygıll, G, İlköğretim düzeyindeki çocuklar için problem çözme envanteri' nin (ÇPÇE) geliştirilmesi. Illköğretim Online, 2010, 9(2), 446-458.

17. Pant, G, Self efficacy and level of aspiration of state level table tennis players. International Journal Advanced. Research, 2016 $4(8), 722-727$

18. Eyüboğlu, E, Spor yapan ve yapmayan 12-14 yas arası ergenlerin öz yeterlik düzeylerinin karşılaştırılması. Yüksek lisans tezi, Haliç Üniversitesi, İstanbul, 2012.

19. Moritz, S.E, Feltz, D.L, Fahrbach, K.R, Mack, D.E, The relation of self-efficacy measures to sport performance: A meta-analytic review. Research quarterly for exercise and sport, 2000, 71(3), 280-294.

20. Efe, M, Öztürk, F, Koparan, Ş, Şenışık, Y, 14-16 yaş grubu erkeklerde voleybol çalışmalarının sosyal yetkinlik beklentisi ve atılganlık üzerine etkisi. Uludağ Üniversitesi Eğitim Fakültesi Dergisi, 2008, 21(1), 69-77.

21. Acar, K, Futbol eğitimi alana çocuklarda problem çözme becerileri ve fonksiyonel olmayan tutumların incelenmesi, 2013, (Doktora Tezi, Selçuk Üniversitesi Sağlık Bilimleri Enstitüsü).

http://edergi.cbu.edu.tr/ojs/index.php/cbusbed isimli yazarın CBU-SBED başlıklı eseri bu Creative Commons Alıntı-Gayriticari4.0 Uluslararası Lisansı ile lisanslanmıștır.

(c) (7) \& 